Vol. 5, No. 02; 2021

ISSN: $2581-3366$

\title{
Effects of Respiratory Therapy and Physical Rehabilitation in a Reduction of Length of ICU Stay among Covid-19 Patients - A Narrative Review
}

\author{
Authors: Mohd. Ashhad Raza Rizvi ${ }^{1}$, Dr. Humaira Hanif $(\mathrm{PT})^{2 *}$, Dr. Nilofar Rasheed (PT) ${ }^{3}$, Dr. \\ Naveen H.Simon ${ }^{4}$ \\ ${ }^{1}$ Graduation-internee, Department of Physiotherapy, Noida International University \\ ${ }^{2}$ Assistant-Professor, Department of Physiotherapy, Noida International University, Greater \\ Noida. \\ ${ }^{3}$ Assistant-professor, Department of Physiotherapy, Noida International University, Greater \\ Noida4Director, Department of Physiotherapy, Noida International University, Greater Noida
}

Corresponding Authors:

Dr. Humaira Hanif(PT)-Assistant Professor, Department of Physiotherapy, Noida International University, Email- humaira.hanif@niu.edu.in

Postal Address: G-52/19 Royal Apt. Sir sayed road Okhla Batlahouse, New Delhi 110025

doi: $10.51505 / \mathrm{ijmshr} .2021 .5208$

URL: http://dx.doi.org/10.51505/ijmshr.2021.5208

\begin{abstract}
Purpose:

The purpose is to determine the effect of both Respiratory Therapy and Physical Rehabilitation in a reduction of length of ICU stay among COVID-19 patients.
\end{abstract}

\section{Materials and Methods:}

A narrative review of the literature was performed by reviewing 61 articles with actual content based on inclusion/exclusion criteria. The articles were searched using various electronic databases like PubMed, Pedro, APTA, WHO, WCPT, Medscape, Scholar, Research-gate. The search strategy included RCTs, cross-sectional study and cohort study.

\section{Results:}

We identified a total of 82 articles from the various electronic database. Among them, 61 articles were shortlisted with actual content-based. The study reported physical rehabilitation and respiratory therapy has improved the physical functioning of ICU patients and has benefitted in respiratory care by enhancing airway clearance and decreased the likelihood of developing ICU associated weakness and leads to reducing the length of ICU stay of COVID-19 patients.

\section{Conclusion:}

This study concluded that both Respiratory therapy and Physical rehabilitation showed a greater effect in reducing the length of ICU stay among COVID-19 patients by reducing the ICU associated complications and enhancing the QOL of patients also has reduced the length of ICU 


\section{International Journal of Medical Science and Health Research}

Vol. 5, No. 02; 2021

ISSN: 2581-3366

stay by 1.4-2.7 days among COVID-19 patients by improving function and decreasing ICU associated complications.

Keywords: COVID-19 critical illness, COVID-19 patients ICU acquired weakness, ICU patient Physical rehabilitation, COVID-19 Patients care, ICU physiotherapy, Respiratory therapy.

\section{Introduction:}

Severe acute respiratory syndrome coronavirus 2 is a new coronavirus that emerged in 2019 and causes COVID-19. (Del Rio C et al 2020, Sohrabi C et al 2020, Guan WJ 2020). This contagious virus is transmitted from one person to another through respiratory secretions. The droplets from coughing, sneezing or rhinorrhoea land on surfaces within 2 meters of the infected person. SARS-CoV-2 remains viable for at least 24 hours on hard surfaces and up to 8hours on soft surfaces. (Van Doremalen N et al 2020).

The World Health Organization emergency medical team recommended that rehabilitation is a core component of patients centre care. Rehabilitation providers must develop plans to receive a large number of patients from acute care facilities, directly from the ICU. ( McNeary L et al 2020, WHO 2016)

Rehabilitation professionals play an important role in speeding up the recovery of those survivors who are admitted to ICU. (Grabowski DC et al 2020). Patients who are admitted to ICU are initially prescribed bed rest, however, causes inactivity and immobility that may lead to significant ICU-related weakness including critical illness polyneuropathy and myopathy report in almost 48\%-96\% respectively. (Herridge MS et al 2020, Stevens RD et al 2007)

Other physical sequelae of ICU stay causes:

-cardiorespiratory deconditioning, postural instability, venous thrombo-embolism in approximately $23 \%$ of patients. (Klok FA et al 2020), muscle shortening and contracture, pressure injuries (Zorowitz RD et al 2020), Ventilator-associated pneumonia in about $19 \%$ of ICU patients. (A. Schauwvlieghe et al 2020), Hypoxic Respiratory Failure in about $16 \%$ of patients.

A study stated that providing physiotherapy services to the admitted patients with confirmed Covid-19 in ICU helps patients being early discharge into wards (Guan W.J et al 2020). Physiotherapy is beneficial in respiratory treatment as well as in the physical treatment of patients with COVID-19. In particularly, Cardiorespiratory Physiotherapy focuses on the management of both acute and chronic respiratory conditions and aims to improve physical recovery following an ICU illness. Those Physiotherapists who practice in the ICU environment provides an airway clearance technique (percussion, vibration, autogenic drainage, FET) for mechanically ventilated patients who show signs of inadequate airway clearance and they assist patients in positioning with severe respiratory failure associated with COVID-19, which includes the use of prone position to optimize oxygenation. (Kress J.P et al 2014, Stiller K et al 2020) 


\section{International Journal of Medical Science and Health Research}

Vol. 5, No. 02; 2021

ISSN: 2581-3366

Early Active and Passive mobilization in the ICU has been an important part of Physical therapy to promoting and optimizing functional independence in activities of daily living as well as to diminish the long ICU stay of patients. Early Active/Passive mobilization is associated with improved muscle strength, better mobility status and improves circulation in the body. (SIMFER guidelines 2020, Tipping CJ et al 2017). The Surveys of physiotherapists from European and Australian ICUs reported that Primary responsibility was to perform respiratory therapy includes airway suctioning, postural drainage (PD), and weaning from mechanical ventilation (MV) (Chaboyer W et al 2004, Norrenberg M et al 2020). Physiotherapy initiated in ICU improves functional status up to one year after discharge from the ICU and can reduce mortality by $25 \%$. (Tomasi CD et al 2020, Wild. D et al 2011).

The purpose of the study is to determine the effect of Physiotherapy Interventions particularly Respiratory Therapy and Physical Rehabilitation on the reduction of length of ICU stay among COVID-19 patients. The study aims to evaluate the effect of Respiratory Therapy and Physical rehabilitation to reduce the length of ICU stay among Covid-19 patients.

\section{Review of literature:}

Respiratory therapy is defined as chest physical therapy which is used to mobilize or lose secretions in the lungs and respiratory tract and helps to drain the lungs and keep respiratory muscle to function properly. (Maximilian S et al, 2008) Respiratory physiotherapy involves external mechanical techniques, such as percussion, postural drainage, mechanical vibration, to augment mobilization and airway clearance secretions, inspiratory muscle training, diaphragmatic breathing with pursed-lip breathing, coughing and controlled coughing. (Maximilian S et al, 2008).

Physical rehabilitation is a multidisciplinary approach focus on early rehabilitation improves physical function neuro-muscular weakness and enhances the quality of life. (Kayambu G et al. 2013). Physical rehabilitation involves an active and passive range of exercises, muscle strengthening, upper limb and lower limb strengthening, ambulation. (Li Z et al, 2013).

All over the world, more than 5 million cases have been confirmed and 400, 000 deaths were reported by the World Health Organization (WHO) as of June 9, 2020. The American region has been shown for the highest number of cases and deaths which was more than 3 million and 200,000 respectively. The European region has been shown for the second-highest confirmed cases and death which were more than 2 million confirmed cases and 183 thousand deaths. The confirmed total number of cases and death in the Eastern Mediterranean region accounted for approximately 660, 000, and 15,000 respectively. (WHO, Report 2020).

The Meta-Analysis was performed to the pooled prevalence of mortality in patients with coronavirus disease in ICU without giving proper care. The 646 articles were identified from different electronic databases and 50 articles were selected for evaluation. Thirty-seven Articles with 24983 participants were included. The Meta-Analysis showed that the prevalence of mortality among ICU admitted patients with Coronavirus was 39\%. The analysis of the pooled prevalence of mortality among ICU admitted patients with COVID-19 showed that the 


\section{International Journal of Medical Science and Health Research}

Vol. 5, No. 02; 2021

ISSN: $2581-3366$

prevalence of ICU mortality among patients with severe acute respiratory syndrome (SARSCoV-2) was 31\% (95\% CI: 26 to 36). (Abate et al, 2020; Ahmed Ali et al, 2020).

Respiratory Intervention like Postural drainage, breathing exercises techniques and secretion clearance techniques are potentially aerosol-generating procedures. (SIMFER guidelines, 2020), Mobilization, Passive and active range of motion should be considered to be important as it leads to coughing or expectoration of secretions. (SIMFER guidelines, 2020, Xie J et al, 2020).

-Physiotherapy in the ICU improves patients' physical wellbeing and quality of Life (QOL): (Dionne F et al, 2012)

- Early mobilization results in decreased length of stay (LOS) in ICU and decreased overall hospital stay. (Morris PE et al 2020).

- Those physiotherapists who are constantly treating patients in the ICU enhance in building a relationship with patients. Also, it has a significant impact on the patient and provide satisfaction. (Dionne F et al, 2012)

- It has already been stated that physical therapy in ICU prevents ICU-related complications, improving bodily functions and enhance QOL. (Dionne F et al 2012, Morris PE et al 2020).

\section{Materials and Methods:}

A narrative review of the literature was performed in which a structured Literature search was done using various Electronic databases like PubMed, Pedro, American physical therapy Association(APTA), World health organization(WHO), World confederation Physical therapy(WCPT), Medscape, Scholar, Research-gate Embase. The search strategy included Clinical trials, randomized controlled trials and cross-sectional study and cohort study. The searching for articles was limited to English literature only.

The search was done by using the following key terms such as; COVID-19 critical illness, COVID-19 patient's ICU acquired weakness, ICU patient Physical rehabilitation, COVID-19 Patients care, ICU physiotherapy, exercise therapy, functional training, the activity of daily living, motor activity, early mobilization, Respiratory therapy, decreased ICU stay, breathing technique.

The articles were allocated based on inclusion and exclusion criteria:

a. Inclusion criteria Include studies with COVID-19 patients who were admitted in an intensive care unit (ICU); Articles regarding PT intervention particularly respiratory therapy and physical rehabilitation in ICU among COVID-19 patients; Articles regarding the importance of PT intervention in enhancing the Respiratory care and physical function and decreasing the length of ICU stay.

b. Exclusion criteria involve Exclusion of articles regarding patients admitted in ICU with neurological conditions such as stroke, Spinal cord injuries; Studies in which patients were not 
admitted in ICU as well as hasn't received any role of Physiotherapy intervention among ICU patients.

The Review have done according to PRISMA

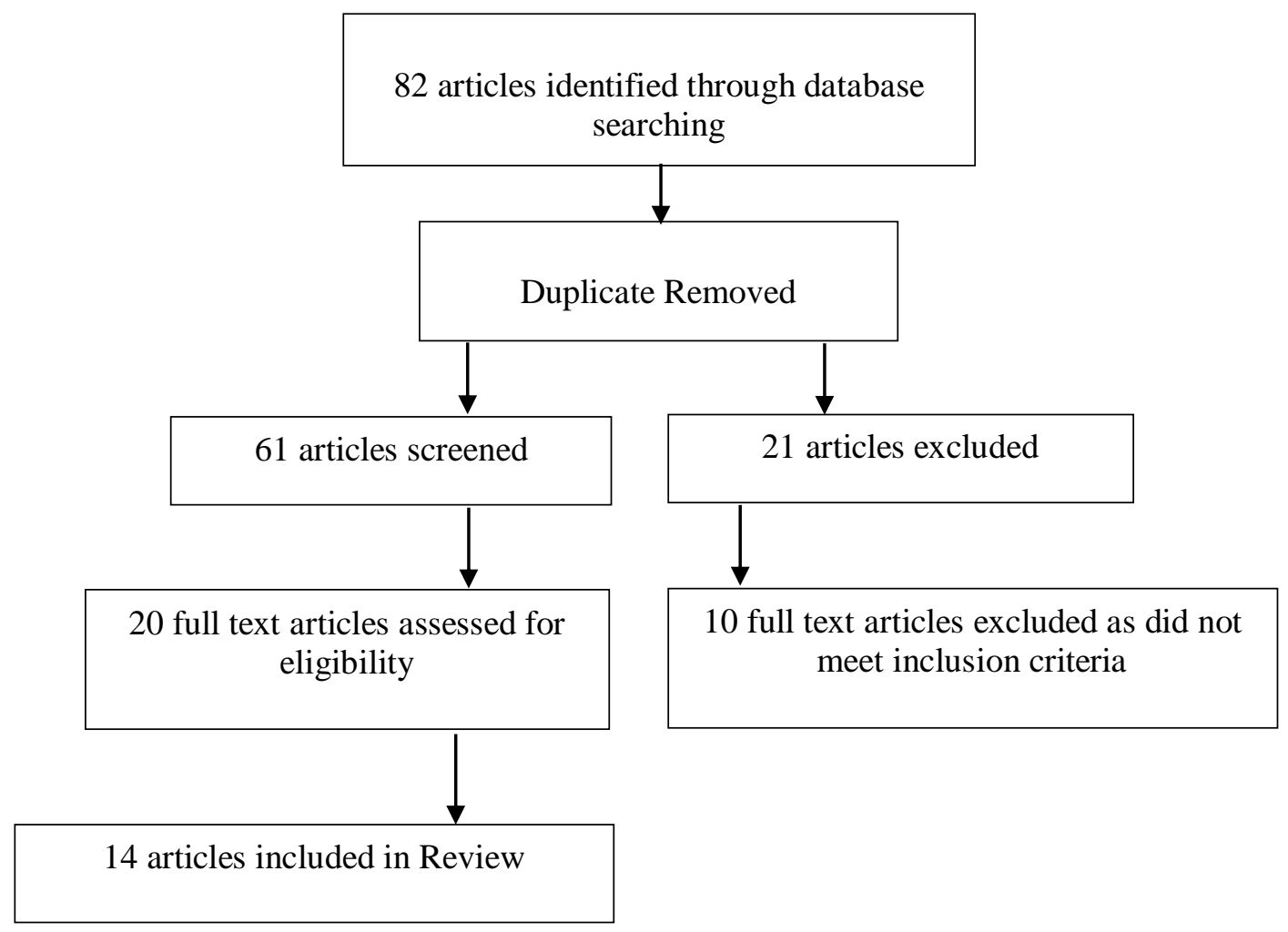

\section{Results:}

We identified a total of 82 articles from the various electronic database. Concerning physical therapy intervention i.e., physical rehabilitation and respiratory therapy, 61 articles were shortlisted with actual content based on Inclusion and exclusion criteria. The study reported both physical therapy intervention decreased the likelihood of developing ICU associated weakness therefore reduces the length of ICU stay of COVID-19 patients.

\subsection{Respiratory Physiotherapy:}

It is defined as chest physical therapy which is used to mobilize or lose secretions in the lungs and respiratory tract and helps to drain the lungs and keep respiratory muscle to function properly. (Maximilian S et al, 2008).

Respiratory physiotherapy consists of external mechanical manoeuvres, such as percussions, postural drainage(PD), vibration, to augment mobilization and clearance of airway secretions, Inspiratory muscle training(IMT), diaphragmatic breathing with pursed-lip breathing, coughing and controlled coughing. (Maximilian S et al, 2008). 


\section{International Journal of Medical Science and Health Research}

Vol. 5, No. 02; 2021

ISSN: 2581-3366

\subsection{Physical Rehabilitation:}

It is a multidisciplinary approach focus on early rehabilitation to improve physical function neuro-muscular weakness and enhance the quality of life. (Kayambu $G$ et al. 2013).

It involves an active and passive range of exercises, muscle strengthening, upper limb and lower limb strengthening, ambulation. (Li Z et al, 2013).

\subsection{ICU based Rehabilitation:}

It is associated with early achievement of mobility milestone and improves muscle strength in relation to respiratory and limb strength. (Li Z et al.2013).

Additionally, an early rehabilitation program in ICU leads to reduced hospital and ICU length of stay, duration of mechanical ventilation and improves the quality of life.

(Needham DM et al. 2008).

\subsection{Physiotherapy Management Categories in ICU patients with COVID-19:}

\section{Category A: Ventilated, Sedated patients-}

Includes patients who are critically ill, sedated, paralyzed and maybe in a prone position. The main goals of Physiotherapy intervention at this stage are:

- To minimize complications of the prolonged recumbent position.

- To facilitate oxygenation.

The physiotherapy management includes passive Range of Motion exercises and Therapeutic positioning. (SIMFER guidelines, 2020).

\section{Category B: Ventilated-minimally sedated patients-}

Design an intervention based on patients conscious level, level of cooperation. The main goals of physiotherapy intervention at this stage are:

- To minimize complications of the prolonged recumbent position.

- To facilitate oxygenation.

- To improve functional independence.

The physiotherapy Management may include; Therapeutic positioning, Range of Motion(ROM) exercises and progressive mobilization. (SIMFER guidelines, 2020, Kallet RH et al 2020).

\section{Category C: Non-Mechanically ventilated patients:}

These patients are divided into 3 categories depending on a conscious level, and functional independence. The main goals of Physiotherapy interventions are:

- To reduce the work of breathing

- To improve lung capacity

- To facilitate oxygenation

- To improve functional capacity (Xie J et al, 2020) 


\section{International Journal of Medical Science and Health Research}

Vol. 5, No. 02; 2021

ISSN: 2581-3366

\section{C1- Minimally Conscious \& bedridden patients:}

Physiotherapy intervention may include Passive ROM exercises and therapeutic positioning. (Xie J et al 2020).

\section{C2- Conscious, Active and dependent patients:}

Physiotherapy intervention may include ROM exercises, Progressive strengthening exercises, progressive mobilization and exercises to improve coordination and balance. Treatment should be design on the patient's oxygen dependency, muscle power and functional independency to optimize functional capacity and promote independence. ((Xie $\mathrm{j}$ et al 2020).

\section{C3- Conscious, Active and independent patients:}

Physiotherapy intervention may include ROM exercises, progressive ambulation and breathing exercises. And exercise program should base on the patient's endurance. (Xie J et al, 2020).

\subsection{Therapeutic Evidence-based practice of Respiratory as well as Physical Intervention in} ICU includes:

- Respiratory Intervention like Postural drainage, Breathing exercises techniques and secretion clearance techniques are potentially aerosol-generating procedures. ( SIMFER guidelines, 2020)

- Mobilization should be considered to be important as it leads to coughing or expectoration of secretions. (SIMFER guidelines, 2020, Xie J et al, 2020))

- Passive and Active Range of Motion Exercises. (Xie J et al, 2020))

\subsection{Benefits of Physiotherapy intervention (Respiratory Therapy and Physical} rehabilitation) on patients experience in ICU:

- Physiotherapy in the ICU improves patients physical wellbeing QOL. (Dionne F et al,2012).

- Early mobilization results in decreased length of stay( LOS) in ICU and decreased overall hospital stay. (Morris PE et al 2020 ).

- Consistency of physiotherapist treating patients in the ICU promotes relationship building and has a significant impact on patients and provider satisfaction. (Dionne F et al,2012)

- Physiotherapy in the ICU prevents ICU-related complications, improving functions and QOL. (Dionne F et al 2012, Morris PE et al 2020).

\section{Discussion:}

The findings from this study stated that early physiotherapy interventions (active mobilization, IMT) in the ICU has numerous benefits. Although positioning is used routinely and has its effects on the pulmonary system. To facilitate weaning, Early active mobilization and Inspiratory muscle training (IMT) needs to be administered early in the ICU. Administration of these physiotherapy techniques will facilitate weaning from mechanical ventilation. We identified that respiratory care and physical rehabilitation plays a vital role in decreasing the Length of ICU stay among COVID-19 patients by improving physical functioning and respiratory care. 


\section{International Journal of Medical Science and Health Research}

Vol. 5, No. 02; 2021

ISSN: 2581-3366

In the study done in the U.S.A, the majority of physiotherapy (73.2\%) required in ICU to treat critically ill patients with confirmed COVID-19. In this study, the evidence for ICU PT intervention suggested that positioning, Mobilization, Manual hyperinflation, percussion and vibrations, suctioning exercises, Active cycle of breathing techniques, Range of motion exercises play the main role fulfilled by the ICU physiotherapists. (Ntoumenopoulos $\mathrm{G}$ et al 2020).

In another study done in Australia, it is concluded that patients received routine chest PT, 55\% stated every $4 \mathrm{~h}$. The efficacy of "chest Physiotherapy," defined as combinations of patients positioning, manual hyperinflation and percussion/vibrations, on short-term patient physiological outcomes has been studied earlier extensively. There is strong evidence to suggest that Physiotherapy treatment found to be extremely effective in recruiting alveoli, enhance secretion clearance, compliance, airway resistance, gas exchange, and reducing the incidence of ventilator acquired pneumonia (VAP) in ICU patients. Therefore, by preventing these ICU related complicated, there was a reduction in the length of ICU stay of about 1.6- 2.0 days (WHO 2020).

\section{CONCLUSION:}

This review of literature has concluded that Physiotherapy interventions particularly Respiratory therapy and Physical rehabilitation showed a greater effect in reducing the length of ICU stay among COVID-19 patients by reducing the ICU associated complications and enhancing the quality of life (QOL) of patients.

The early mobilization and respiratory therapy were associated with a greater likelihood of being discharged onto wards from ICU.

The most evident reason for requiring intensive care has been Respiratory support. It is also concluded from several studies that Physiotherapy intervention has reduced ICU length of stay (LOS) by 1.4-2.7 days among COVID-19 patients by improving function and reducing the number of complications associated with an ICU.

\section{Future research Recommendation}

The future recommendation can be to determine the efficacy of PT intervention in maintaining the long-term physical function after hospital discharge or To determine to what extent the ICU non-COVID-19 patients are at risk for prolonged respiratory, physical and functional limitations in need of rehabilitation.

\section{Ethics approval and consent to participate}

Not applicable.

\section{Availability of data and materials}

All data, a total of 61 studies, were analyzed during this study.

\section{Funding}

This research has not received any specific grant from funding companies. 


\section{Abbreviations:}

ICU- Intensive Care Unit

APTA- American Physical Therapy Association

WCPT- World Confederation for Physical Therapy

WHO- World Health Organization

QOL- Quality of Life

LOS- Length of Stay

ROM-Range of Motion

IMT- Inspiratory Muscle Training

SARS-Severe acute respiratory syndrome

CoV2 -coronavirus 2

FET- Forced Expiration Technique

PT- Physiotherapy

VAP- Ventilator acquired pneumonia

RMST-Respiratory muscle strength training

TEE-Thoracic expansion exercises

ADLs-Activities of daily living

MV- mechanical ventilation

PD- postural drainage

MDT-Multidisciplinary team

ICUAW-Intensive care unit acquired weakness 
Table 1

Characteristics of the included studies.

\begin{tabular}{|c|c|c|c|c|}
\hline $\begin{array}{l}\text { Auth } \\
\text { or }\end{array}$ & Study title & $\begin{array}{l}\text { Intervent } \\
\text { ion }\end{array}$ & ign & Summary Of relevant findings \\
\hline $\begin{array}{l}\text { Tran } \\
\text { DH et } \\
\text { al } \\
2020\end{array}$ & $\begin{array}{l}\text { Ambulatory } \\
\text { Status is } \\
\text { associated with } \\
\text { successful } \\
\text { Discharge home } \\
\text { in survivors of } \\
\text { Critical Illness } \\
\text { from COVID- } \\
19\end{array}$ & $\begin{array}{l}\text { Early } \\
\text { Mobilizati } \\
\text { on in ICU } \\
\text { patient }\end{array}$ & $\begin{array}{l}\text { A } \\
\text { retrosp } \\
\text { ective } \\
\text { cohort } \\
\text { study }\end{array}$ & $\begin{array}{l}\text { The study concluded that ambulating the } \\
\text { patients have shown a higher possibility of } \\
\text { being early discharged of Covid- } 19 \\
\text { patients from ICU, emphasizing the } \\
\text { importance of early mobilization in ICU. }\end{array}$ \\
\hline $\begin{array}{l}\text { Toma } \\
\text { si CD } \\
\text { et al } \\
2010\end{array}$ & $\begin{array}{l}\text { The beneficial } \\
\text { effect of } \\
\text { respiratory } \\
\text { physiotherapy } \\
\text { in ICU patients } \\
\text { ventilated for } \\
\text { more than } 48 \\
\text { hours }\end{array}$ & $\begin{array}{l}\text { Respirator } \\
\text { y } \\
\text { physiother } \\
\text { apy\& } \\
\text { mobilizatio } \\
\text { n }\end{array}$ & $\begin{array}{l}\text { a } \\
\text { random } \\
\text { ized } \\
\text { control } \\
\text { led } \\
\text { trial }\end{array}$ & $\begin{array}{l}\text { The study has shown that physiotherapy } \\
\text { intervention in critical care has helped } \\
\text { reduce the mortality rate by } 25 \% \text {, prevents } \\
\text { ICU related complications and reduced the } \\
\text { patient's stay in ICU as well as an overall } \\
\text { hospital stay. }\end{array}$ \\
\hline $\begin{array}{l}\text { Hodg } \\
\text { son C. } \\
\text { L. et } \\
\text { al } \\
2014\end{array}$ & $\begin{array}{l}\text { Recommendatio } \\
\text { ns for active } \\
\text { mobilization of } \\
\text { mechanically } \\
\text { ventilated } \\
\text { critically ill } \\
\text { adults }\end{array}$ & $\begin{array}{l}\text { Early } \\
\text { mobilizatio } \\
\text { n \& limb } \\
\text { physiother } \\
\text { apy }\end{array}$ & $\begin{array}{l}\text { systemi } \\
\text { c } \\
\text { literatur } \\
\text { e of } \\
\text { review }\end{array}$ & $\begin{array}{l}\text { The study stated that the recommendations of } \\
\text { early mobilization in mechanically ventilated } \\
\text { patients have the potential to minimize the } \\
\text { risk of adverse effects associated with ICU } \\
\text { and in turn improve the functional outcomes } \\
\text { and reduced ICU and hospital length of stay. }\end{array}$ \\
\hline $\begin{array}{l}\text { Enriq } \\
\text { ue et } \\
\text { al } \\
2013\end{array}$ & $\begin{array}{l}\text { Interventions to } \\
\text { Improve the } \\
\text { Physical } \\
\text { Function of ICU } \\
\text { Survivor }\end{array}$ & $\begin{array}{l}\text { Physical } \\
\text { functional } \\
\text { rehab } \\
\text { (exercises) }\end{array}$ & $\begin{array}{l}\text { a } \\
\text { systemi } \\
\mathrm{c} \\
\text { review } \\
\text { of } \\
\text { literatur } \\
\mathrm{e} \\
\end{array}$ & $\begin{array}{l}\text { The study concluded that early Exercises by } \\
\text { Physiotherapists seems to be the only } \\
\text { treatment shown to improve long-term } \\
\text { physical functions of critically ill patients in } \\
\text { ICU }\end{array}$ \\
\hline $\begin{array}{l}\text { Baidy } \\
\text { a et al } \\
2016\end{array}$ & $\begin{array}{l}\text { Physiotherapy } \\
\text { practice } \\
\text { interventions in } \\
\text { Intensive Care } \\
\text { Units of Nepal }\end{array}$ & $\begin{array}{l}\text { Chest } \\
\text { physiother } \\
\text { apy }\end{array}$ & $\begin{array}{l}\text { a } \\
\text { cross- } \\
\text { section } \\
\text { al study }\end{array}$ & $\begin{array}{l}\text { The study concluded that the most common } \\
\text { and effective type of Physiotherapy } \\
\text { treatment performed on critically ill patients } \\
\text { in ICU is Chest PT (53.8\%) and positioning } \\
(21.2 \%)\end{array}$ \\
\hline Hosey & Survivorship & Evidence- & A & The study concluded that critically ill \\
\hline
\end{tabular}




\begin{tabular}{|c|c|c|c|c|}
\hline $\begin{array}{l}\text {, M.M } \\
\text { et al } \\
2020\end{array}$ & $\begin{array}{l}\text { after the } \\
\text { COVID-19 ICU } \\
\text { stay }\end{array}$ & $\begin{array}{l}\text { based } \\
\text { critical } \\
\text { care } \\
\text { interventio } \\
\mathrm{n} \text {, prone- } \\
\text { positioning } \\
\text {, physical } \\
\text { rehabilitati } \\
\text { on, early } \\
\text { mobilizatio } \\
\text { n }\end{array}$ & $\begin{array}{l}\text { random } \\
\text { ized } \\
\text { controll } \\
\text { ed trial }\end{array}$ & $\begin{array}{l}\text { patients with COVID-19 will face physical } \\
\text { and respiratory impairments. To optimize } \\
\text { both survival and survivorship of critically ill } \\
\text { patients in ICU, Evidence-based critical care } \\
\text { interventions are required to deliver that } \\
\text { includes prone-positioning, physical } \\
\text { rehabilitation, early mobilization to reduce } \\
\text { muscle weakness and duration of mechanical } \\
\text { ventilation. }\end{array}$ \\
\hline $\begin{array}{l}\text { Simps } \\
\text { on, R } \\
\text { et al } \\
2020\end{array}$ & $\begin{array}{l}\text { Rehabilitation } \\
\text { after critical } \\
\text { illness in } \\
\text { patients with } \\
\text { COVID-19 } \\
\text { infection }\end{array}$ & $\begin{array}{l}\text { Functional } \\
\text { training \& } \\
\text { respiratory } \\
\text { rehab. }\end{array}$ & $\begin{array}{l}\text { a } \\
\text { random } \\
\text { ized } \\
\text { controll } \\
\text { ed trial }\end{array}$ & $\begin{array}{l}\text { The study concluded that Rehabilitation } \\
\text { professionals will have a critical role in } \\
\text { assisting patients from ICU associated } \\
\text { illness, helps to optimize independent } \\
\text { function, facilitate community re-integration } \\
\text { and managing respiratory care. }\end{array}$ \\
\hline $\begin{array}{l}\text { Kathe } \\
\text { rine E } \\
\text { et al } \\
2009\end{array}$ & $\begin{array}{l}\text { Physical therapy } \\
\text { Utilization in } \\
\text { Intensive care } \\
\text { units (ICU) } \\
\text { among critically } \\
\text { Ill patients }\end{array}$ & $\begin{array}{l}\text { therapeutic } \\
\text { exercises } \\
\text { and } \\
\text { functional } \\
\text { retraining } \\
\text { \&chronic } \\
\text { physical } \\
\text { therapy }\end{array}$ & $\begin{array}{l}\text { a } \\
\text { cross- } \\
\text { section } \\
\text { al study }\end{array}$ & $\begin{array}{l}\text { It is concluded that therapeutic exercises and } \\
\text { functional retraining are commonly used for } \\
\text { ICU patients recovering from critical illness } \\
\text { and Based on the results of this study, a } \\
\text { European Respiratory Society and European } \\
\text { Society of Intensive Care Medicine Task } \\
\text { Force concluded that there was expert } \\
\text { opinion evidence regarding the effectiveness } \\
\text { of long term or chronic physical therapy for } \\
\text { critically ill adults. }\end{array}$ \\
\hline $\begin{array}{l}\text { Anup } \\
\text { Bhat } \\
\text { et al } \\
2017\end{array}$ & $\begin{array}{l}\text { Role of } \\
\text { physiotherapy } \\
\text { in weaning of } \\
\text { patients from } \\
\text { mechanical } \\
\text { ventilation in } \\
\text { the Intensive } \\
\text { Care Unit }\end{array}$ & $\begin{array}{l}\text { Respirator } \\
\mathrm{y} \\
\text { physiother } \\
\text { apy \&early } \\
\text { mobilizatio } \\
\mathrm{n} \quad \& \\
\text { Inspiratory } \\
\text { muscle } \\
\text { training }\end{array}$ & $\begin{array}{l}\text { a } \\
\text { random } \\
\text { ized } \\
\text { controll } \\
\text { ed trial }\end{array}$ & $\begin{array}{l}\text { concluded that early initiation of } \\
\text { physiotherapy through Early mobilization } \\
\text { and Inspiratory muscle training (IMT) } \\
\text { facilitates faster weaning of patients from } \\
\text { ventilators and also decreased length of stay } \\
\text { in ICU and the clinical benefits observed } \\
\text { with early physiotherapy suggest the need to } \\
\text { implement early physiotherapy to all } \\
\text { critically ill patients admitted to the ICU }\end{array}$ \\
\hline $\begin{array}{l}\text { Dr } \\
\text { Vittor } \\
\text { ia et } \\
\text { al } \\
2019\end{array}$ & $\begin{array}{l}\text { Respiratory } \\
\text { physiotherapy } \\
\text { in critically ill } \\
\text { patients }\end{array}$ & $\begin{array}{l}\text { Respirator } \\
\text { y } \\
\text { rehabilitati } \\
\text { on \& \& } \\
\text { physical } \\
\text { function }\end{array}$ & $\begin{array}{l}\text { Review } \\
\text { of } \\
\text { literatur } \\
\mathrm{e}\end{array}$ & $\begin{array}{l}\text { They stated that the survival rate of patients } \\
\text { with life-threatening conditions who are } \\
\text { admitted to an ICU has significantly } \\
\text { increased through physiotherapy And } \\
\text { respiratory rehabilitation has become a } \\
\text { cornerstone in the comprehensive }\end{array}$ \\
\hline
\end{tabular}




\begin{tabular}{|c|c|c|c|c|}
\hline & & $\begin{array}{l}\text { rehabilitati } \\
\text { on. }\end{array}$ & & $\begin{array}{l}\text { management of ICU- patients that determine } \\
\text { short-term benefits, preventing some ICU } \\
\text { complications, such as PICS and ICUAW, } \\
\text { and preserving or recovering patients' } \\
\text { functionality. The strategies of intervention } \\
\text { should be applied in the early stage of } \\
\text { illness, as soon as the patient gets } \\
\text { cardiorespiratory and neurological } \\
\text { stabilization. }\end{array}$ \\
\hline $\begin{array}{l}\text { Bastia } \\
n \\
\text { Meije } \\
r \text { et al } \\
2020\end{array}$ & $\begin{array}{l}\text { Recommendatio } \\
\text { ns for } \\
\text { Physiotherapy } \\
\text { intervention in } \\
\text { COVID-19 for } \\
\text { ICU patient }\end{array}$ & $\begin{array}{l}\text { Early } \\
\text { mobilizatio } \\
\mathrm{n} \\
\text { \&physical } \\
\text { function } \\
\text { rehab. }\end{array}$ & $\begin{array}{l}\text { a } \\
\text { cross- } \\
\text { section } \\
\text { al study }\end{array}$ & $\begin{array}{l}\text { They concluded that there is increasing } \\
\text { evidence that reducing bed rest and inactivity } \\
\text { as much as possible by early mobilization in } \\
\text { the chair and activation in the ICU, are } \\
\text { promising PT interventions to prevent and } \\
\text { reduce the consequences of bed rest, } \\
\text { inactivity and critical illness and improves } \\
\text { patients health in ICU }\end{array}$ \\
\hline $\begin{array}{l}\text { Karim } \\
\text { M et } \\
\text { al } \\
2020\end{array}$ & $\begin{array}{l}\text { Recommendatio } \\
\text { ns for Hospital- } \\
\text { Based Physical } \\
\text { Therapists } \\
\text { Managing } \\
\text { Patients With } \\
\text { COVID-19 }\end{array}$ & $\begin{array}{l}\text { Breathing } \\
\text { exercises, } \\
\text { ACBT, } \\
\text { Respirator } \\
\text { y muscle } \\
\text { strength } \\
\text { training, } \\
\text { Mobility } \\
\text { training. }\end{array}$ & $\begin{array}{l}\text { review } \\
\text { of } \\
\text { literatur } \\
\text { e }\end{array}$ & $\begin{array}{l}\text { They concluded that when patients are } \\
\text { critically ill and admitted to the ICU, and } \\
\text { when patients are severely ill and admitted to } \\
\text { the COVID ward. Physical therapist } \\
\text { management for patients hospitalized with } \\
\text { COVID-19 comprises elements of } \\
\text { respiratory support and early mobilization. } \\
\text { Respiratory support includes breathing } \\
\text { techniques, thoracic expansion } \\
\text { exercises(TEE), airway clearance techniques, } \\
\text { and respiratory muscle strength } \\
\text { training(SMST). The Recommendations } \\
\text { toward Early mobilization include activities } \\
\text { of bed mobility, active range of } \\
\text { motion(ROM) exercises, active-assisted limb } \\
\text { exercises, ADLs training, transfer training, } \\
\text { cycling ergometer, pre-gait exercises, and } \\
\text { ambulation }\end{array}$ \\
\hline $\begin{array}{l}\text { MS } \\
\text { Ajims } \\
\text { ha et } \\
\text { al } \\
2020\end{array}$ & $\begin{array}{l}\text { Acute Care } \\
\text { Physiotherapy } \\
\text { Management of } \\
\text { COVID-19 } \\
\text { Patients in } \\
\text { Qatar: } \\
\text { Consensus- }\end{array}$ & $\begin{array}{l}\text { Early } \\
\text { mobilizatio } \\
\text { n, } \\
\text { pulmonary } \\
\text { rehabilitati } \\
\text { on, } \\
\text { physical }\end{array}$ & $\begin{array}{l}\text { a } \\
\text { random } \\
\text { ized } \\
\text { controll } \\
\text { ed trial }\end{array}$ & $\begin{array}{l}\text { The study concluded that the rates of } \\
\text { admission to an ICU are approximately 18- } \\
25 \% \text { with critical illness and Physiotherapist } \\
\text { are considered as an integral part of } \\
\text { multidisciplinary team (MDT) of ICU and } \\
\text { other critical wards. They focus on the early } \\
\text { mobilization of critically ill patients along }\end{array}$ \\
\hline
\end{tabular}




\section{International Journal of Medical Science and Health Research}

Vol. 5, No. 02; 2021

ISSN: $2581-3366$

\begin{tabular}{|c|c|c|c|c|}
\hline & $\begin{array}{l}\text { Based } \\
\text { Recommendatio } \\
\text { ns }\end{array}$ & $\begin{array}{l}\text { rehabilitati } \\
\text { on. }\end{array}$ & & $\begin{array}{l}\text { with their vital role in pulmonary hygiene. } \\
\text { Physiotherapy found to be beneficial in the } \\
\text { respiratory treatment and physical functional } \\
\text { rehabilitation of patients with COVID-19 } \\
\text { positive along with its proven role to prevent } \\
\text { or delay ICU acquired weakness, } \\
\text { delirium(confusion) and other complications } \\
\text { arise from immobility induced from } \\
\text { prolonged ventilation. }\end{array}$ \\
\hline $\begin{array}{l}\text { Anew } \\
\text { DE et } \\
\text { al } \\
2020\end{array}$ & $\begin{array}{l}\text { Early } \\
\text { rehabilitation } \\
\text { reduces the } \\
\text { likelihood of } \\
\text { developing } \\
\text { intensive care } \\
\text { unit-acquired } \\
\text { weakness }\end{array}$ & $\begin{array}{l}\text { Early } \\
\text { mobilizatio } \\
\text { n \& } \\
\text { physical } \\
\text { rehabilitati } \\
\text { on }\end{array}$ & $\begin{array}{l}\text { A } \\
\text { random } \\
\text { ized } \\
\text { controll } \\
\text { ed trial }\end{array}$ & $\begin{array}{l}\text { The study concluded that Early rehabilitation } \\
\text { to ICU patients has decreased the likelihood } \\
\text { of developing ICU associated weakness } \\
\text { however reduced the prolonged ICU stay }\end{array}$ \\
\hline
\end{tabular}

\section{References:}

A Schauwvlieghe, B.J.A. Rijnders, N. Philips, R. Verwijs, L. Vanderbeke, C. Van Tienen, et al. Invasive aspergillosis in patients admitted to the intensive care unit with severe influenza: a retrospective cohort study. (2020 March)

Abate SM, Ahmed Ali S, Mantfardo B, Basu B (2020) Rate of Intensive Care Unit admission and outcomes among patients with coronavirus: A systematic review and Meta-analysis. PLOS ONE 15(7): e0235653. https://doi.org/10.1371/journal.pone.0235653

Anekwe DE, Biswas S, Bussières A, Spahija J. Early rehabilitation reduces the likelihood of developing intensive care unit-acquired weakness: a systematic review and meta-analysis. Physiotherapy. 2020; 107:1-10. doi: 10.1016/j.physio.2019.12.004

Anup Bhat, Abraham Samuel B, Lenny T. Role of physiotherapy in weaning of patients from mechanical ventilation in the Intensive Care Unit. Indian journal of respiratory care. 2017; Vol-6(2): 813-819. DOI: 10.4103/ijrc.ijrc_8_17

Baidya, Sumana et al. "Physiotherapy practice patterns in Intensive Care Units of Nepal: A multicenter survey." Indian journal of critical care medicine: peer-reviewed, official publication of Indian Society of Critical Care Medicine vol. 20,2 (2016): 84-90. doi:10.4103/0972-5229.175939

Bastiaan Meijeer et al, Grill et al, (2020). Recommendations for Physiotherapy intervention in COVID-19 for ICU patientsVol 1(1). 


\section{International Journal of Medical Science and Health Research}

Vol. 5, No. 02; 2021

ISSN: 2581-3366

Chaboyer W, Gass E, Foster M. Patterns of chest physiotherapy in Australian Intensive Care Units. J Crit Care. 2004;19(3):145-151

Del Rio C, Malani PN. 2019 Novel Coronavirus-Important Information for Clinicians. JAMA. 2020;323(11):1039-1040.

Dionne F. 2012 Valuation of Physiotherapy Services in Canada; CPA report using MCDA analysis for determining the value of physiotherapy services; Mitton $\mathrm{G}$

Dr. Vittoria, Prof Antoni, Prof Stefano (2019). Respiratory physiotherapy in critically ill patients. Icu Management and practice; vol-19(2).

Enrique Calve-Ayala, MD; Babar A. Khan, MD; Mark O. Farber. Interventions to Improve the Physical Function of ICU Survivors, CHEST 2013; 144(5):1469-1480

Grabowski DC, Joynt Maddox KE: Post-acute care preparedness for COVID-19: thinking ahead. JAMA 2020; doi: 10.1001/jama.2020.4686. [Epub ahead of print] [PubMed]

Guan WJ, Ni ZY, Hu Y, Liang WH, Ou CQ, He JX, et al. Clinical Characteristics of Coronavirus Disease 2019 in China. New Engl J Med. 2020. Early online: 29 February, 2020

Herridge MS, Moss M, Hough CL, et al.: Recovery and outcomes after the acute respiratory distress syndrome (ARDS) in patients and their family caregivers. Intensive Care Med 2016;42:725-38 [PubMed]

Hodgson, C. L., Stiller, K., Needham, Webb, S. A. (2014). Expert consensus and recommendations on safety criteria for active mobilisation of mechanically ventilated critically ill adults. Critical care (London, England), 18(6), 658. https://doi.org/10.1186/s13054-014-0658-y

Hosey, M.M., Needham, D.M. Survivorship after COVID-19 ICU stay. Nat Rev Dis Primers 6, 60 (2020). https://doi.org/10.1038/s41572-020-0201-1

Kallet RH, Hemphill JC, Dicker RA, Alonso JA, Campbell AR, Mackersie RC, Katz JA. The spontaneous breathing pattern and work of breathing of patients in managing Covid-19 respiratory health. 2020;395(10229):1054-1062

Karin M. Felten-Barentsz, Emily Klooster (2020). Recommendations for Hospital-Based Physical Therapists Managing Patients with COVID-19. American Physical Therapy Association; pzaa114, https://doi.org/10.1093/ptj/pzaa114

Katherine E. Hodgin, Amy Nor-don-Craft. Physical Therapy Utilization in Intensive Care Units for critically ill patients. Crit Care Med. 2009 February; 37(2): 561-568. doi:10.1097/CCM.0b013e3181957449

Kayambu G, Boots R, Paratz J 41(6):1543-54. Physical therapy for the critically ill in the ICU: a systematic review and meta-analysis, Crit Care Med. 2013 Jun;

Klok FA, Kruip MJHA, van der Meer NJM, et al. Incidence of thrombotic complications in critically ill ICU patients with COVID-19. Thromb Res. Published online April 10, 2020. doi:10.1016/j.thromres.2020.04.013PubMedGoogle Scholar 


\section{International Journal of Medical Science and Health Research}

Vol. 5, No. 02; 2021

ISSN: $2581-3366$

Kress J.P., Hall J.B. ICU-acquired weakness and recovery from critical illness. N Engl J Med. 2014; 370:1626-1635. [PubMed] [Google Scholar]

Li Z, Peng X, Zhu B, Zhang Y, Xi X Arch Active mobilization for mechanically ventilated patients: a systematic review; Phys Med Rehabil. 2013 Mar; 94(3):551-61

Maximilian S. Zach, Béatrice Oberwaldner. 2008. Chest Physiotherapy. Pediatric Respiratory Medicine, 241-251

McNeary L, Maltser S, Verduzco-Gutierrez M: Navigating coronavirus disease 2019 (Covid-19) in physiatry: a CAN report for inpatient rehabilitation facilities. PM R 2020; doi: 10.1002/pmrj.12369. [Epub ahead of print] [PubMed]

Morris PE, Goad A, Thompson C, Taylor K, Harry B, Passmore L, Ross A, Anderson L, Baker S, Sanchex M, Penley L, Howard A, Dixon L, Leach S, Small R, Hite RD, Hapnik E. Early intensive care unit mobility therapy in the treatment of acute respiratory failure. Critical Care Medicine. 2008; 36:2238-2243

MS Ajimsha et al, Neeraj et al, Shameem et al, (2020). Acute Care Physiotherapy Management of COVID-19 Patients in Qatar: Consensus-Based Recommendations. Department of Physiotherapy, Hamad Medical Corporation; Vol-1; doi:10.20944/preprints202004. 0417.v1

Needham DM, mobilizing patients in the intensive care unit: improving neuromuscular weakness and physical function. JAMA. 2008 Oct 8; 300(14):1685-90

Norrenberg M, Vincent JL. A profile of European intensive care unit physiotherapists. European Society of Intensive Care Medicine. Intensive Care Med. 2020;26(7):988-994

Ntoumenopoulos G, Presneill JJ, McElholum M, Cade JF. Chest physiotherapy for the prevention of ventilator-associated pneumonia. Intensive Care Med. $2020 \mathrm{Jul}$; 2(7):850-6.

Simpson, R., \& Robinson, L. (2020). Rehabilitation After Critical Illness in People with COVID19 Infection. American journal of physical medicine \& rehabilitation, 99(6), 470-474. https://doi.org/10.1097/PHM.0000000000001443

SIMFER. 2020, Recommendations for Respiratory Rehabilitation of COVID-19 in Adult SIMFER [Internet]. [cited 12 April 2020]. 2020;395(10223):507-513

Sohrabi C, Alsafi Z, O'Neill N, Khan M, Kerwan A, Al-Jabir A, et al. World Health Organization declares global emergency: A review of the 2019 novel coronavirus (COVID-19). Int J Surg. 2020; 76:71-76.

Stevens RD, Dowdy DW, Michaels RK, et al.: Neuromuscular dysfunction acquired in critical illness: a systematic review. Intensive Care Med 2007;33:1876-91 [Google Scholar]

Stiller K. Physiotherapy in intensive care: an updated systematic review. Chest. 2020; 144:825847. (PubMed) 
Vol. 5, No. 02; 2021

ISSN: 2581-3366

Tipping CJ, Harrold M, Holland A, et al.: The effects of active mobilisation and rehabilitation in ICU on mortality and function: a systematic review. Intensive Care Med 2017; 43:17183

Tomasi CD, Figueiredo F, Constantino L, Grandi R, Topanotti MFL, Giombelli V, Dal-Pizzol F, Ritter C. Beneficial effect of respiratory physiotherapy in critically ill patients ventilated for more than 48 hours: A randomized controlled trial. Intensive Care Medicine. Conference 23rd Annual Congress of the European Society of Intensive Care Medicine, ESICM Barcelona Spain. Date of publication: September 2010.

Tran DH, Maheshwari P, Nagaria Z, Patel HY, Verceles AC. Ambulatory Status is associated with successful Discharge home in survivors of Critical Illness from COVID-19. Respiratory Care. 2020 Mar 31.

Wild D. Pushing mobility can reduce costs, deaths, in ICU patients. Clinical Anesthesiology. 2011; 37:8

World Health Organization, Coronavirus disease 2019 (COVID-19) Situation Report 46, 2020.

World Health Organization: Emergency medical teams: minimum technical standards and recommendations for rehabilitation. 2016

WHO Director-General's opening remarks at the media briefing on COVID-19 - 11 March 2020 [Internet]. Who. int. 2020 [cited 12 April 2020]

WHO Director-General's opening remarks at the media briefing on COVID-19 - 11 March 2020 [Internet]. Who. int. 2020 [cited 12 April 2020]

Xie J, Tong Z, Guan X, Du B, Qiu H, Slutsky A. Critical care crisis and some recommendations during the COVID-19 epidemic in China. Intensive Respiratory care. 2020 March 1; 52 (8):989-95.

Zorowitz RD: ICU-acquired weakness: a rehabilitation perspective of diagnosis, treatment, and functional management. Chest 2020; 150:966-71 